\title{
$J M M$

\section{ANALISIS PENGARUH KEPEMIMPINAN ISLAMI DAN ETOS KERJA ISLAMI TERHADAP KINERJA ISLAMI PEGAWAI DENGAN BUDAYA ORGANISASI ISLAMI SEBAGAI MODERATING VARIABEL (STUDI PADA RUMAH SAKIT ISLAM SITI HAJAR MATARAM)}

\author{
M. Aswadi ${ }^{1}$ \\ Lalu Suparman ${ }^{2}$ \\ Zainal Abidin ${ }^{3}$ \\ Email: aswadi87@gmail.com
}

\begin{abstract}
This research is aimed at analyzing and determining the significance of the effect of Islamic leadership on the Islamic performance, analyzing and determining the significance of the effect of Islamic work ethic on the Islamic performance, analyzing and determining the significance of the effect of Islamic organizational culture on the Islamic performance, analyzing determining the significance of the leadership on the Islamic performance with Islamic organizational culture as moderating variable, and analyzing and determining the significance of the effect Islamic work ethic on the Islamic performance with Islamic organizational culture as moderating variable.

The population of this research are all 261 employees working in Islamic Hospital of Siti Hajar Mataram. The sample were 72 respondent. The analysis were performance to examine the hypothesis with PLS-SEM analysis using smartPLS 3.0.

The research showed that the Islamic leadership had positive but no significant effect on Islamic performance, the Islamic work ethic had positive and significant effect on Islamic performance, the Islamic organizational culture had positive and significant effect on the Islamic performance, the Islamic organizational culture did not strengthen the effect Islamic leadership on the Islamic performance, while the Islamic organizational culture strengthened the effect Islamic work ethic on the Islamic performance.
\end{abstract}

Keywords: Islamic leadership, Islamic work ethic, Islamic organizational culture, Islamic performance.

\section{Pendahuluan}

Sumber daya manusia (SDM) merupakan satu-satunya sumber daya yang memiliki akal perasaan, keinginan, keterampilan, pengetahuan, dorongan, daya dan karya. Semua potensi SDM tersebut berpengaruh terhadap upaya organisasi dalam mencapai tujuan. Betapapun majunya teknologi, perkembangan informasi, tersedianya modal dan memadainya bahan, jika tanpa SDM sulit bagi organisasi itu untuk mencapai tujuannya (Sutrisno, 2015, p.3). Oleh karena itu memaksimalkan potensi yang ada pada sumber daya manusia adalah salah satu cara untuk meningkatkan kinerja dalam mencapai tujuan organisasi.

Menurut Gibson et al., (1994) dalam Rivai et al., (2010, p.26) kinerja adalah keberhasilan didalam melaksanakan tugas serta kemampuan untuk mencapai tujuan yang telah ditetapkan. Kinerja dinyatakan baik dan sukses jika tujuan yang diinginkan dapat tercapai dengan baik. Banyak faktor yang dapat memengaruhi kinerja sumber daya

\footnotetext{
${ }^{1}$ Freelance

${ }^{2}$ Magister Manajemen Universitas Mataram

${ }^{3}$ Magister Manajemen Universitas Mataram
} 


\section{$J M M$

manusia. Menurut Gibson et al., (1996, p.123-124) faktor-faktor yang memengaruhi kinerja adalah faktor dari variabel individu yang terdiri dari kemampuan dan kecakapan, latar belakang, dan variabel demografis. Faktor yang memengaruhi kinerja yang kedua adalah faktor dari variabel psikologis yang terdiri dari persepsi, sikap, kepribadian, motivasi, kepuasan kerja dan stres kerja. Sedangkan faktor yang ketiga adalah faktor organisasi yang terdiri dari kepemimpinan, kompensasi, konflik, kekuasaan, struktur organisasi, desain pekerjaan, desain organisasi dan karir.

Sebagaimana disebutkan di atas, salah satu faktor yang memengaruhi kinerja adalah kepemimpinan. Kepemimpinan merupakan persoalan yang sangat penting dalam Islam karena kepemimpinan berkaitan dengan kemaslahatan umat seperti keadilan, kesejahteraan, keamanan dan kenyamanan. Dalam pandangan Islam setiap manusia adalah pemimpin dan tiap-tiap pemimpin akan dimintai pertanggungjawabannya. Sebagaimana dijelaskan dalam sebuah Hadits yang artinya : "Setiap orang di antara kalian adalah pemimpin dan akan dimintai tanggung jawab atas kepemimpinannya." (HR. Bukhari dan Muslim). Menurut Rivai et al., (2013, p.29) kepemimpinan Islam adalah suatu proses atau kemampuan orang lain untuk mengarahkan dan memotivasi tingkah laku orang lain, serta ada usaha kerjasama sesuai dengan Al-Qur'an dan Hadits untuk mencapai tujuan yang diinginkan bersama. Untuk meningkatkan kinerja maka peran pemimpin sangat diperlukan demi tercapainya tujuan organisasi.

Menurut Hasibuan dalam Wijayanti dan Wajdi (2012, p.108) selain faktor motivasi dan kepuasan kerja, kepemimpinan yang Islami juga mempunyai peran yang sangat besar dalam meningkatkan kinerja karyawan. Beberapa penelitian terdahulu telah menemukan bahwa kepemimpinan Islami berpengaruh signifikan terhadap kinerja Islami. Diantaranya adalah penelitian Shahab (2010), Hakim (2012), Wijayanti dan Wajdi (2012) dan Syamsuddin (2014). Namun walaupun beberapa penelitian menunjukkan bahwa kepemimpinan Islami berpengaruh signifikan terhadap kinerja Islami, penelitian Suparman (2012) dan Mappamiring (2015) justru menemukan bahwa kepemimpinan Islami tidak berpengaruh signifikan terhadap kinerja Islami.

Disamping kepemimpinan, faktor yang memengaruhi kinerja adalah faktor psikologis yang meliputi sikap dan keperibadian berupa etos kerja. Etos berasal dari bahasa Yunani (ethos) yang memberikan arti sikap, keperibadian, watak, karakter, serta keyakinan atas sesuatu (Tasmara, 2002, p.15). Etos kerja muslim didefinisikan sebagai sikap keperibadian yang melahirkan keyakinan yang sangat mendalam bahwa bekerja itu bukan saja untuk memuliakan dirinya, menampakkan kemanusiaannya, melainkan juga sebagai suatu manifestasi dari amal saleh dan oleh karenanya mempunyai nilai ibadah yang sangat luhur (Tasmara, 2002, p.27).

Beberapa penelitian empiris menyebutkan bahwa etos kerja Islami memiliki hubungan dan pengaruh terhadap kinerja. Diantara penelitian yang menemukan bahwa etos kerja Islami berpengaruh positif dan signifikan terhadap kinerja adalah Hayati dan Caniago (2012), Imam et al., (2013), Desky (2014), dan Nurmatias (2015). Namun berbeda dengan hasil penelitian di atas, penelitian yang dilakukan oleh Sutono dan Budiman (2009) menemukan bahwa etos kerja Islami tidak berpengaruh signifikan terhadap kinerja karyawan.

Selain kepemimpinan dan etos kerja, budaya organisasi dapat dikatakan sebagai bagian dari variabel organisasi yang dapat memengaruhi kinerja karyawan. Budaya organisasi didefinisikan sebagai norma, nilai-nilai, asumsi, kepercayaan, filsafat, kebiasaan organisasi, dan sebagainya yang dikembangkan dalam waktu yang lama oleh pendiri, pemimpin dan anggota organisasi yang disosialisasikan dan diajarkan kepada 
anggota baru serta diterapkan dalam aktivitas organisasi sehingga memengaruhi pola pikir, sikap, dan perilaku anggota organisasi dalam memproduksi produk, melayani para konsumen, dan mencapai tujuan organisasi (Wirawan, 2007, p.10). Sedangkan Budaya organisasi dalam persepektif Islam menurut Sumarman (2003) dalam Hakim (2012), adalah nilai apapun pikiran dan simbol berdasarkan Islam, norma-norma yang memengaruhi perilaku, sikap, iman dan kebiasaan seseorang dalam jalan-jalan hidup tertentu.

Sejumlah penelitian empiris menunjukkan bahwa budaya organisasi mempunyai peran besar dalam upaya mencapai tujuan organisasi. Akan tetapi sejumlah penelitian juga menunjukkan bahwa budaya organisasi dapat menghambat perkembangan organisasi (Wirawan, 2007, p.35). Hasil penelitian Suryo (2010), Setyorini (2012), Giri et al., (2016), menemukan bahwa budaya organisasi berpengaruh positif dan signifikan terhadap kinerja karyawan. Hasil tersebut didukung oleh hasil penelitian Hakim (2012) dan Mappamiring (2015) yang menemukan bahwa budaya organisasi Islami berpengaruh positif dan signifikan terhadap kinerja Islami. Namun berbeda dengan penelitian Lina (2014), Haryanti (2015) dan Lousyiana et al., (2015) menemukan bahwa budaya organisasi tidak berpengaruh signifikan terhadap kinerja.

Tuntutan untuk meningkatkan dan mempertahankan kinerja tinggi tentunya di alami oleh semua organisasi tidak terkecuali Rumah Sakit Islam Siti Hajar Mataram. Rumah Sakit Islam Siti Hajar Mataram merupakan bentuk usaha yang bergerak dibidang jasa pelayanan kesehatan yang bernaung dibawah Yayasan Rumah Sakit Islam Nusa Tenggara Barat (YARSI NTB) yang didirikan pada tanggal 7 Rabi'ul Awal 1396 H bertepatan dengan tanggal 8 Maret 1976. Berdirinya rumah sakit ini awalnya disambut baik oleh umat Islam NTB dikarenakan pelayanannya yang bernuansa Islami. Namun banyaknya organisasi atau perusahaan yang bergerak di bidang pelayanan kesehatan menuntut pihak Rumah Sakit Islam Siti Hajar Mataram untuk selalu memperbaiki kinerjanya.

Berdasarkan data yang di peroleh dari Rumah Sakit Islam Siti Hajar Mataram jumlah pasien dari tahun ke tahun cenderung mengalami penurunan. Hal ini dapat dilihat dari tabel 1.1 rekapitulasi jumlah pasien yang dirawat inap dan rawat jalan tahun 2011 s.d 2015.

Tabel 1.1. Jumlah Pasien Rawat Inap dan Rawat Jalan pada Rumah Sakit Islam Siti Hajar Mataram Tahun 2011 s.d 2015

\begin{tabular}{|c|c|c|}
\hline No. & Tahun & Jumlah Pasien (Orang) \\
\hline 1. & 2011 & 16680 \\
\hline 2. & 2012 & 16442 \\
\hline 3. & 2013 & 16276 \\
\hline 4. & 2014 & 15763 \\
\hline 5. & 2015 & 18763 \\
\hline
\end{tabular}

Sumber: Rumah Sakit Islam Siti Hajar Mataram 2016

Tabel 1.1 di atas menunjukkan bahwa jumlah pasien yang dirawat inap dan rawat jalan di Rumah Sakit Islam Siti Hajar Mataram mengalami penurunan dari tahun 2012 s.d 2014 dan hanya mengalami peningkatan di tahun 2015. Hal ini mengindikasikan bahwa kinerja pegawai Rumah Sakit Islam Siti Hajar Mataram selama lima tahun terakhir masih belum optimal dan konsisten. Oleh karena itu untuk dapat bertahan dan bersaing ditengah ketatnya persaingan maka kinerja Islami pegawai harus menjadi perhatian serius organisasi. Karena kinerja organisasi tergantung dari kinerja individu (Gibson et al., 1996, p.13). 


\section{$J M M$

Berdasarkan teori, penelitian terdahulu dan fenomena di atas maka penulis tertarik untuk meneliti tentang "Analisis Pengaruh Kepemimpinan Islami dan Etos Kerja Islami Terhadap Kinerja Islami Pegawai dengan Budaya Organisasi Islami Sebagai Moderating Variabel (Studi pada Rumah Sakit Islam Siti Hajar Mataram)".

\section{Metode Penelitian}

Jenis penelitian yang digunakan dalam penelitian ini adalah kuantitatif kausal. Hubungan kausal adalah hubungan yang bersifat sebab akibat (Sugiyono, 2014, p.37). Populasi dalam penelitian ini adalah seluruh pegawai Rumah Sakit Islam Siti Hajar Mataram yang berjumlah 261 orang dengan rincian sebagai berikut:

Tabel 2.1. Jumlah Populasi

\begin{tabular}{|c|c|c|}
\hline No. & Unit Kerja & Jumlah Populasi \\
\hline 1. & Dokter & 10 \\
\hline 2. & Perawat & 89 \\
\hline 3. & Bidan & 12 \\
\hline 4. & Pegawai Laboratorium & 12 \\
\hline 5. & Pegawai Radiologi & 6 \\
\hline 6. & Pegawai Farmasi & 16 \\
\hline 4. & Pegawai Non Medis & 116 \\
\hline & Jumlah & 261 \\
\hline
\end{tabular}

Sumber : Rumah Sakit Islam Siti Hajar Mataram (2016)

Karena populasi sudah diketahui maka teknik pengambilan sampel menggunakan rumus dari Taro Yamane atau Slovin yaitu sebagai berikut :

$\mathrm{n}=\frac{\mathrm{N}}{\mathrm{N} \cdot \mathrm{d}^{2}+1}$

Keterangan :

$\mathrm{n}$ = Jumlah sampel

$\mathrm{N}=$ Jumlah Populasi

$\mathrm{d}^{2}=$ Presisi (ditetapkan 10\% dengan tingkat kepercayaan 95\%)

Berdasarkan rumus tersebut diperoleh jumlah sampel sebagai berikut:

$\mathrm{n}=\frac{261}{(261) \cdot 0,1^{2}+1}=\frac{261}{3.61}=72$

Jumlah sampel yang diteliti sebesar 72 responden. Berhubung responden bekerja di unit kerja yang berbeda maka pengambilan sampel dilakukan secara proporsional random sampling. 


\section{$J M M$ UNRAM

Tabel 2.2. Pemilihan Sampel dengan Proporsional Random Sampling

\begin{tabular}{|c|c|c|c|c|}
\hline No. & Unit Kerja & $\begin{array}{c}\text { Jumlah } \\
\text { Populasi }\end{array}$ & $\begin{array}{l}\text { Teknik Proporsional } \\
\text { Random Sampling }\end{array}$ & $\begin{array}{l}\text { Jumlah } \\
\text { Sampel }\end{array}$ \\
\hline 1 & Dokter & 10 & $(10 / 261) * 72$ & 3 \\
\hline 2 & Perawat & 89 & $(89 / 261)^{\star 72}$ & 25 \\
\hline 3 & Bidan & 12 & $(12 / 261) * 72$ & 3 \\
\hline 4 & Pegawai Laboratorium & 12 & $(12 / 261) * 72$ & 3 \\
\hline 5 & Pegawai Radiologi & 6 & $(6 / 261)^{* 72}$ & 2 \\
\hline 6 & Pegawai Farmasi & 16 & $(16 / 261) * 72$ & 4 \\
\hline 7 & Pegawai Non Medis & 116 & $(116 / 227) * 72$ & 32 \\
\hline & Jumlah & 261 & & 72 \\
\hline
\end{tabular}

Sumber: Rumah Sakit Islam Siti Hajar Mataram 2016 (data diolah)

Data dalam penelitian ini pada dasarnya adalah data kualitatif yang dirubah menjadi data kuantitatif yaitu berupa skor yang diperoleh dari tiap jawaban dalam kuesioner yang disebar kepada responden. Sumber data yang digunakan dalam penelitian ini adalah data primer yakni data yang diperoleh secara langsung dan bersumber dari responden dan data sekunder yakni data pendukung yang diperoleh dari naskah tertulis, buku, jurnal serta literatur lainnya yang bersifat melengkapi data primer. Untuk memperoleh data yang diperlukan dalam penelitian ini digunakan beberapa teknik pengumpulan yaitu interview (wawancara), kuesioner dan observasi.

Adapun variabel-variabel yang dianalisis dalam penetian ini adalah kepemimpinan Islami $(X 1)$, etos kerja Islami $(X 2)$, budaya organisasi Islami $(Z)$ dan kinerja Islami $(Y)$.

1) Variabel Kinerja Islami; yang dimaksud dalam penelitian ini adalah cara bekerja atau perilaku yang ditunjukkan para pegawai Rumah Sakit Islam Siti Hajar Mataram dalam melaksanakan tugas dan tanggung jawabnya untuk mencapai tujuan organisasi mengikuti kaidah-kaidah Islam.

2) Variabel Kepemimpinan Islami; yang dimaksud dalam penelitian ini adalah persepsi para responden (pegawai Rumah Sakit Islam Siti Hajar Mataram) atas sikap dan perilaku Direktur Rumah Sakit Islam Siti Hajar Mataram dalam menjalankan fungsi-fungsi kepemimpinan seperti menyampaikan visi, misi, tujuan dan program kerja; mendistribusikan tugas pekerjaan kepada para pegawai; memberikan perintah dan arahan menjalankan tugas; memberikan motivasi, memberikan penghargaan kepada pegawai; melaksanakan pengawasan dan memberikan umpan balik. Sikap dan perilaku tersebut didasari oleh sifat-sifat Rasulullah yaitu siddiq, amanah, tabligh dan fathanah.

3) Variabel Etos Kerja Islami; yang dimaksud dalam penelitian ini adalah karakter dan kebiasaan pegawai Rumah Sakit Islam Siti Hajar Mataram dalam bekerja yang dibentuk dan dipengaruhi oleh keimanan dan nilai-nilai Islam, yang kemudian membentuk semangat yang membedakannya dengan pegawai lainnya.

4) Variabel Budaya Organisasi Islami; yang dimaksud dalam penelitian ini adalah persepsi para pegawai Rumah Sakit Islam Siti Hajar Mataram terhadap norma, nilai-nilai, dan kebiasaan organisasi yang dikembangkan oleh pendiri, pemimpin dan anggota organisasi dengan berlandaskan pada nilai-nilai Islam yaitu AlQur'an dan Hadits yang digunakan sebagai pedoman dalam melaksanakan tugas sehari-hari untuk mencapai tujuan organisasi.

Penelitian ini menggunakan analisis deskriptif yang digunakan untuk menganalisis data dengan cara mendeskripsikan atau menggambarkan data yang sudah 
terkumpul sebagaimana adanya tanpa bermaksud membuat kesimpulan yang berlaku untuk umum atau generalisasi (Sugiyono, 2002, p.169). Kemudian analisis data dan pengujian hipotesis dalam penelitian ini menggunakan analisis Partial Least Squares Structural Equation Modeling (PLS-SEM).

\subsection{Analisis Data}

\section{Pembahasan}

Pengujian hipotesis dalam penelitian ini menggunakan analisis Partial Least Squares - Structural Equation Modeling (PLS-SEM). Adapun model evaluasi dalam penelitian ini dilakukan dengan menilai outer model dan inner model.

\section{Outer Model}

Evaluasi model pengukuran atau outer model dilakukan untuk menilai validitas dan reliabilitas model. Penelitian ini menggunakan konstruk dengan indikator refleksif atau mode A oleh karena itu terdapat tiga nilai yang harus diperhatikan pada tahap ini yaitu convergent validity, discriminant validity dan composite reliability.

\section{1) Convergent Validity}

Validitas convergent berhubungan dengan prinsip bahwa pengukur-pengukur (manifest variabel) dari suatu konstruk seharusnya berkorelasi tinggi. Uji validitas convergent indikator refleksif dapat dilihat dari nilai loading faktor untuk tiap indikator konstruk. Rule of thumb yang biasanya digunakan untuk menilai validitas convergent yaitu nilai loading factor harus $>0.7$. 


\section{JMM JURNAL MAGISTER MANAJEMEN

Tabel 3.1. Outer Loadings (Measurement Model)

\begin{tabular}{|c|c|c|c|}
\hline No. & Variabel & Indikator & $\begin{array}{c}\text { Outer } \\
\text { Loading }\end{array}$ \\
\hline \multirow{7}{*}{1} & \multirow{7}{*}{ Kepemimpinan Islami } & $\mathrm{X} 1.01$ & 0,753 \\
\hline & & X1.02 & 0,910 \\
\hline & & X1.03 & 0,861 \\
\hline & & $\mathrm{X} 1.03$ & 0,921 \\
\hline & & X1.04 & 0,848 \\
\hline & & $\mathrm{X} 1.05$ & 0,810 \\
\hline & & X1.06 & 0,815 \\
\hline \multirow{7}{*}{2} & \multirow{7}{*}{ Etos Kerja Islami } & $X 2.01$ & 0,787 \\
\hline & & $\mathrm{X} 2.02$ & 0,825 \\
\hline & & $\mathrm{X} 2.03$ & 0,824 \\
\hline & & $\mathrm{X} 2.04$ & 0,873 \\
\hline & & $\mathrm{X} 2.05$ & 0,872 \\
\hline & & $\mathrm{X} 2.06$ & 0,850 \\
\hline & & $\mathrm{X} 2.07$ & 0,854 \\
\hline \multirow{8}{*}{3} & \multirow{8}{*}{ Budaya Organisasi Islami } & Z.01 & 0,858 \\
\hline & & Z.02 & 0,905 \\
\hline & & Z.03 & 0,850 \\
\hline & & Z.04 & 0,909 \\
\hline & & Z.05 & 0,876 \\
\hline & & Z.06 & 0,853 \\
\hline & & Z.07 & 0,911 \\
\hline & & Z.08 & 0,807 \\
\hline \multirow{7}{*}{4} & \multirow{7}{*}{ Kinerja Islami } & Y.01 & 0,757 \\
\hline & & Y.02 & 0,791 \\
\hline & & Y.03 & 0,825 \\
\hline & & $\mathrm{Y} .04$ & 0,822 \\
\hline & & Y.05 & 0,835 \\
\hline & & Y.06 & 0,767 \\
\hline & & Y.07 & 0,785 \\
\hline
\end{tabular}

Sumber : Data pimer diolah

Berdasarkan Tabel 3.1 dapat dilihat bahwa semua indikator variabel memiliki nilai loading di atas 0,70 . Sehingga semua indikator dapat dinyatakan memenuhi convergen validity. Hal ini berarti bahwa semua indikator pada variabel dapat dijadikan sebagai pengukur variabel. Nilai loading faktor tertinggi dan terendah terdapat pada indikator kepemimpinan Islami yakni indikator (X1.03) dengan nilai loading faktor sebesar 0,921. Sedangkan nilai loading faktor terendah terdapat pada indikator (X1.01) dengan nilai loading faktor sebesar 0,753.

\section{2) Discriminant Validity}

Untuk uji validitas dapat juga dilihat dari uji discriminant validity yaitu membandingkan masing-masing akar kuadrat AVE terhadap nilai korelasi antar konstruk. Jika nilai akar kuadrat AVE lebih tinggi dibandingkan nilai korelasi antar konstruk, maka dinyatakan memenuhi kriteria discriminant validity (Ghozali \& Latan, 2015, p.96). Untuk hasil output discriminant validity dapat dilihat pada tabel 6.2 berikut: 


\section{IMM JURNAL MAGISTER MANAJEMEN

Tabel 3.2. Hasil Uji Discriminant Validity

\begin{tabular}{|l|c|c|c|c|c|c|}
\hline \multicolumn{1}{|c|}{ Variabel } & $\mathbf{X}_{\mathbf{1}}$ & $\mathbf{X}_{\mathbf{2}}$ & $\mathbf{Z}$ & $\mathbf{Y}$ & $\begin{array}{c}\text { Mod } \\
\text { Effect 1 }\end{array}$ & $\begin{array}{c}\text { Mod } \\
\text { Effect 2 }\end{array}$ \\
\hline Kepemimpinan Islami $\left(\mathrm{X}_{1}\right)$ & $\mathbf{0 , 8 4 7}$ & & & & & \\
\hline Etos Kerja Islami $\left(\mathrm{X}_{2}\right)$ & 0,445 & $\mathbf{0 , 8 4 1}$ & & & & \\
\hline Budaya Organisasi Islami $(\mathrm{Z})$ & 0,304 & 0,830 & $\mathbf{0 , 8 7 2}$ & & & \\
\hline Kinerja Islami $(\mathrm{Y})$ & 0.404 & 0,755 & 0,715 & $\mathbf{0 , 7 9 8}$ & & \\
\hline Moderating Effect 1 & 0,695 & 0,283 & 0,135 & 0,244 & $\mathbf{0 , 8 3 4}$ & \\
\hline Moderating Effect 2 & 0,366 & 0,355 & 0,244 & 0,469 & 0,601 & $\mathbf{0 , 7 1 6}$ \\
\hline
\end{tabular}

Sumber: Data pimer diolah

Berdasarkan Tabel 3.2 dapat di jelaskan bahwa diagonal adalah nilai akar kuadrat AVE dan nilai di bawahnya adalah korelasi antar konstruk. Jadi terlihat bahwa nilai akar kuadrat AVE lebih tinggi daripada nilai korelasi. Sehingga dapat disimpulkan bahwa model telah valid karena telah memenuhi discriminant validity.

3) Composite Reliability

Composite reliability bertujuan untuk menguji reliabilitas suatu konstruk. Uji reliabilitas dilakukan untuk membuktikan akurasi, konsistensi dan ketepatan instrumen dalam mengukur konstruk. Hasil pengujian composite reliability dapat dilihat pada Tabel 4.2.berikut:

Tabel 3.3. Hasil Pengujian Composite Reliability dan AVE

\begin{tabular}{|l|c|c|}
\hline \multicolumn{1}{|c|}{ Varibel } & $\begin{array}{c}\text { Average Veriance } \\
\text { Extracted (AVE) }\end{array}$ & $\begin{array}{c}\text { Composite } \\
\text { Reliability }\end{array}$ \\
\hline Kepemimpinan Islami (X1) & 0,718 & 0,947 \\
\hline Etos Kerja Islami (X2) & 0,708 & 0,944 \\
\hline Budaya Organisasi Islami (Z) & 0,760 & 0,962 \\
\hline Kinerja Islami & 0,637 & 0,925 \\
\hline Moderating Effect 1 & 0,695 & 0,992 \\
\hline Moderating Effect 2 & 0,513 & 0,983 \\
\hline
\end{tabular}

Sumber: Data pimer diolah

Berdasarkan Tabel 3.3 dapat dilihat bahwa nilai AVE yang dihasilkan oleh semua variabel/konstruk yaitu di atas 0,50 sehingga memenuhi persyaratan reliabilitas. Begitu juga nilai Composite Reliability yang dihasilkan semua variabel sangat baik yaitu di atas 0,70 . Sehingga dapat disimpulkan bahwa semua indikator konstruk adalah reliabel atau memenuhi uji reliabilitas.

\section{Inner Model}

Evaluasi model struktural atau inner model bertujuan untuk memprediksi hubungan antar variabel laten. Evaluasi inner model dapat dilihat dari beberapa indikator yang meliputi:

\section{1) Koefisien Determinasi (R2)}

Dalam menilai model dengan PLS dimulai dengan melihat R-square untuk setiap variabel endogen. Perubahan R-Squares dapat digunakan untuk menjelaskan pengaruh variabel laten eksogen tertentu terhadap variabel laten endogen apakah mempunyai pengaruh yang substantive. Berikut adalah hasil estimasi R-Square dengan menggunakan PLS.

Tabel 3.4 Nilai R Square

\begin{tabular}{|c|c|}
\hline Varibel & R Square \\
\hline Kinerja Islami & 0,670 \\
\hline
\end{tabular}

Sumber : Data pimer diolah 


\section{$J M M$

Berdasarkan Tabel 3.4 dapat dilihat nilai $\mathrm{R}$ Square untuk variabel kinerja Islami sebesar 0,670 yang berarti termasuk dalam katagori kuat. Artinya bahwa variabel kinerja Islami dapat dijelaskan oleh varibel kepemimpinan Islami, etos kerja Islami dan budaya organisasi Islami sebesar $67 \%$ atau dengan kata lain bahwa pengaruh variabel kepemimpinan Islami (X1) dan etos kerja Islami (X2) terhadap kinerja Islami (Y) dengan budaya organisasi Islami (Z) sebagai moderator adalah sebesar $67 \%$ dan sisanya $33 \%$ dipengaruhi oleh variabel lain di luar model penelitian ini.

\section{2) Effecet Size $f^{2}$}

Teknik ini dilakukan untuk mengetahui kebaikan model. Nilai $f^{2}$ 0,02, 0,15 dan 0,35 diinterpretasikan bahwa prediktor variabel laten memiliki pengaruh kecil, menengah, dan besar pada level struktural. Untuk lebih jelasnya berikut disajikan hasil dari perthitungan nilai f square untuk effect size $f^{2}$ variabel laten.

Tabel 3.5. Nilai f Square

\begin{tabular}{|l|c|c|c|c|c|c|}
\hline \multicolumn{1}{|c|}{ Variabel } & $\mathbf{X}_{\mathbf{1}}$ & $\mathbf{X}_{\mathbf{2}}$ & $\mathbf{Z}$ & $\mathbf{Y}$ & $\begin{array}{c}\text { Mod } \\
\text { Effect 1 }\end{array}$ & $\begin{array}{c}\text { Mod } \\
\text { Effect 2 }\end{array}$ \\
\hline Kepemimpinan Islami $\left(\mathrm{X}_{1}\right)$ & & & & 0,046 & & \\
\hline Etos Kerja Islami $\left(\mathrm{X}_{2}\right)$ & & & & 0,107 & & \\
\hline Budaya Organisasi Islami $(\mathrm{Z})$ & & & & 0,083 & & \\
\hline Kinerja Islami $(\mathrm{Y})$ & & & & & & \\
\hline Moderating Effect 1 & & & & 0,059 & & \\
\hline Moderating Effect 2 & & & & 0,197 & & \\
\hline
\end{tabular}

Sumber : Data pimer diolah

Berdasarkan Tabel 3.5 dapat dijelaskan bahwa $f^{2}$ untuk effect size kepemimpinan Islami terhadap kinerja Islami sebesar 0,046 $(<0,15)$, etos kerja Islami terhadap kinerja Islami sebesar 0,107 $(<0,15)$, budaya organisasi Islami terhadap kinerja Islami sebesar $0,083(<0,15)$. Ketiganya dinilai lemah karena di bawah 0,15 . Selanjutnya $f^{2}$ moderating effect 1 terhadap kinerja Islami sebesar 0,059 $(<0,15)$ dinilai lemah karena dibawah 0,15. Sementara $f^{2}$ moderating effect 2 terhadap kinerja Islami sebesar 0,197 $(>0,15)$ dinilai moderate karena lebih dari 0,15.

3) Predictive Relevance $\left(Q^{2}\right)$

Teknik ini dapat merepresentasi synthesis dari cross-validation dan fungsi fitting dengan prediksi dari observed variabel dan estimasi dari parameter konstruk. Nilai $Q^{2}>0$ menunjukkan bahwa model mempunyai predictive relevance, sedangkan nilai $Q^{2}<0$ menunjukkan bahwa model kurang memiliki predictive relevance. $Q^{2}$ dapat dihitung dengan rumus sebagai berikut :

$Q^{2}=1-\left(1-R_{1}{ }^{2}\right)\left(1-R_{2}{ }^{2}\right)\left(1-R_{3}{ }^{2}\right) \ldots\left(1-R_{n}{ }^{2}\right)$

Keterangan:

$Q^{2}=Q$ Square (predictive relevance)

$\mathrm{R}^{2}=$ Koefisien determinasi

$Q^{2}=1-(1-0,670)$

$Q^{2}=1-0,33$

$Q^{2}=0,67$

Berdasarkan perhitungan diatas maka didapatkan hasil sebesar 0,685. Hasil ini menunjukkan bahwa model memiliki nilai predictive-relevance karena nilai yang dihasilkan $>0$.

4) Goodness of Fit Index (GoF)

GoF merupakan ukuran tunggal yang digunakan untuk memvalidasi performa gabungan antara model pengukuran (outer model) dan model struktural (inner model), dan 
disamping itu menyediakan pengukuran sederhana untuk keseluruhan dari prediksi model. Untuk overall fit index dapat menggunakan kriteria goodness of fit (GoF index) yang dikembangkan oleh Tenenhaus et al., (2004) dalam Ghozali dan Latan $(2015$, p.82). Index ini dikembangkan untuk mengevaluasi model pengukuran dan model struktural dan disamping itu menyediakan pengukuran sederhana untuk keseluruhan dari prediksi model. Menurut Tenenhau (2004) dalam Hussein (2015), nilai GoF small = 0,1, GoF medium $=0,25$ dan GoF besar $=0,38$. Untuk mencari nilai GoF pada PLS-SEM harus dilakukan dengan cara manual yaitu.:

$$
\begin{aligned}
\text { GoF } & =\sqrt{\overline{A V E} \times \overline{R^{2}}} \ldots \ldots . . \text { Tenenhaus (2004) } \\
\text { GoF } & =\sqrt{0,672} \times 0,670 \\
& =\sqrt{0,450} \\
& =0,671
\end{aligned}
$$

Berdasarkan hasil perhitungan di atas maka diperoleh nilai GoF sebesar 0,671 yang berarti model struktural terkait kepemimpinan Islam dan etos kerja Islami terhadap kinerja Islami dengan budaya organisasi Islami sebagai moderating variabel termasuk dalam katagori robust (kuat) sehinggga pengujian hipotesa dapat dilakukan.

\subsection{Pengujian Hipotesis}

Menguji hipotesis dapat dilihat dari nilai t-statistik dan nilai probabilitas. Untuk pengujian hipotesis menggunakan nilai statistik, maka untuk alpha 5\% nilai t-statistik yang digunakan adalah 1.96. Sehingga kriteria penerimaan/penolakan hipotesa adalah Ha diterima dan $\mathrm{H} 0$ ditolak ketika t-statistik $>1,96$.

Tabel 3.6. Hasil Pengujian Hipotesis Berdasarkan Path Coefficient

\begin{tabular}{|l|c|c|c|c|c|}
\hline Varibel & $\begin{array}{c}\text { Original } \\
\text { Sampel }\end{array}$ & $\begin{array}{c}\text { Standar } \\
\mathrm{d} \text { Error }\end{array}$ & $\begin{array}{c}\text { T- } \\
\text { Statistics }\end{array}$ & $\begin{array}{c}\text { P } \\
\text { Value }\end{array}$ & $\begin{array}{c}\text { Hasil Uji } \\
\text { Hipotesis }\end{array}$ \\
\hline $\begin{array}{l}\text { Kepemimpinan Islami } \rightarrow \\
\text { Kinerja Islami }\end{array}$ & 0,188 & 0,120 & 1,567 & 0,059 & $\begin{array}{c}\text { Tidak } \\
\text { Signifikan }\end{array}$ \\
\hline $\begin{array}{l}\text { Etos Kerja Islami } \rightarrow \text { Kinerja } \\
\text { Islami }\end{array}$ & 0,368 & 0,146 & 2,522 & 0,006 & Signifikan \\
\hline $\begin{array}{l}\text { Budaya Organisasi Islami } \rightarrow \\
\text { Kinerja Islami }\end{array}$ & 0,302 & 0,131 & 2,305 & 0,011 & Signifikan \\
\hline $\begin{array}{l}\text { Moderating Effect 1 } \rightarrow \text { Kinerja } \\
\text { Islami }\end{array}$ & $-0,379$ & 0,245 & 1,550 & 0,061 & $\begin{array}{l}\text { Tidak } \\
\text { Signifikan }\end{array}$ \\
\hline $\begin{array}{l}\text { Moderating Effect 2 } \rightarrow \text { Kinerja } \\
\text { Islami }\end{array}$ & 0,643 & 0,184 & 3,495 & 0,000 & Signifikan \\
\hline
\end{tabular}

Sumber: Data pimer diolah

Berdasarkan Tabel 3.6 dapat diketahui bahwa dari 5 hipotesis yang diajukan 3 hipotesis menunjukkan hasil yang signifikan, sementara 2 hipotesis lainnya menunjukkan hasil yang tidak signifikan. Adapun model strukturalnya dapat dilihat pada gambar 4.1 berikut: 


\section{$J M M$

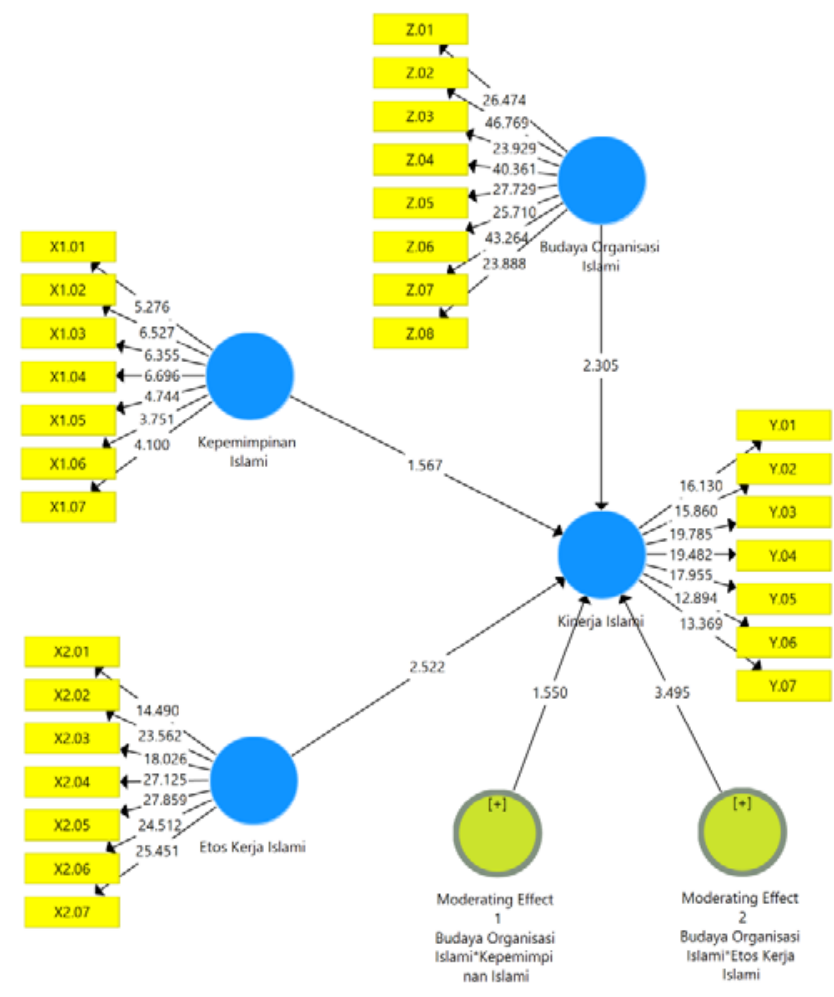

Gambar 3.1 Model Struktural Hasil Uji PLS

Berdasarkan Tabel 3.6 dan gambar 3.1 di atas dapat dijelaskan bahwa :

1. Nilai original sampel dari kepemimpinan Islami ke kinerja Islami sebesar 0,188 menunjukkan bahwa arah hubungan kepemimpinan Islami terhadap kinerja Islami positif. Sementara nilai $\mathrm{t}$ statistik dari kepemimpinan Islami ke kinerja Islami sebesar 1,567 ( $\mathrm{t}$ hitung $<\mathrm{t}$ tabel 1,96) menunjukkan bahwa pengaruh kepemimpinan Islami terhadap kinerja Islami tidak signifikan. Dengan demikian dapat dikatakan bahwa pengaruh kepemimpinan Islami terhadap kinerja Islami positif namun tidak signifikan.

2. Nilai original sampel dari etos kerja Islami ke kinerja Islami sebesar 0,368 menunjukkan arah hubungan etos kerja Islami terhadap kinerja Islami adalah positif. Sementara nilai $t$ statistik dari etos kerja Islami ke kinerja Islami sebesar 2,522 (t hitung $>\mathrm{t}$ tabel 1,96) menunjukkan pengaruh etos kerja Islami terhadap kinerja Islami signifikan. Dengan demikian dapat dikatakan bahwa etos kerja Islami berpengaruh positif dan signifikan terhadap kinerja Islami.

3. Nilai original sampel dari budaya organisasi Islami ke kinerja Islami sebesar 0,302 menunjukkan arah hubungan budaya organisasi Islami terhadap kinerja Islami adalah positif. Sementara nilai $t$ statistik dari budaya organisasi Islami ke kinerja Islami sebesar 2,305 ( $t$ hitung $>t$ tabel 1,96) menunjukkan pengaruh budaya organisasi Islami terhadap kinerja Islami signifikan. Dengan demikian dapat dikatakan bahwa budaya organisasi Islami berpengaruh positif dan signifikan terhadap kinerja Islami.

4. Nilai original sampel dari moderating effect 1 ke kinerja Islami sebesar -0,379 menunjukkan arah hubungan moderating effect 1 terhadap kinerja Islami adalah negatif. Sementara nilai t statistik dari moderating effect 1 ke kinerja Islami sebesar 1,550 ( $\mathrm{t}$ hitung $<\mathrm{t}$ tabel 1,96) menunjukkan pengaruh moderating effect 1 terhadap 


\section{$J M M$

kinerja Islami tidak signifikan. Hal ini berarti bahwa budaya organisasi Islami tidak memperkuat pengaruh kepemimpinan Islami terhadap kinerja Islami.

5. Nilai original sampel dari moderating effect 2 ke kinerja Islami sebesar 0,643 menunjukkan arah hubungan moderating effect 2 terhadap kinerja Islami adalah positif. Sementara nilai $t$ statistik dari moderating effect 2 ke kinerja Islami sebesar 3,495 (t hitung $>\mathrm{t}$ tabel 1,96) menunjukkan pengaruh moderating effect 2 terhadap kinerja Islami signifikan. Hal ini berarti bahwa budaya organisasi Islami memperkuat pengaruh etos kerja Islami terhadap kinerja Islami.

\subsection{Pembahasan Hasil Penelitian}

Penelitian ini dilakukan untuk memperoleh pemahaman tentang pengaruh kepemimpinan Islami dan etos kerja Islami terhadap kinerja Islami dengan dimoderasi budaya organisasi Islami. Dengan mengacu pada tujuan penelitian dan merujuk pada hasil pengujian hipotesis maka penjelasan terhadap hasil pengujian hipotesis tersebut dapat diuraikan sebagai berikut:

\subsubsection{Pengaruh Kepemimpinan Islami terhadap Kinerja Islami Pegawai}

Hasil penelitian ini menguji pengaruh kepemimpinan Islami terhadap kinerja Islami pegawai pada Rumah Sakit Islam Siti Hajar Mataram. Hasil penelitian menunjukkan bahwa pengaruh kememimpinan Islami terhadap kinerja Islami positif namun tidak signifikan. Berdasarkan hasil yang diperoleh pada penelitian ini, maka hipotesis yang menyatakan bahwa diduga kepemimpinan Islami berpengaruh positif dan signifikan terhadap kinerja Islami pegawai Rumah Sakit Islam Siti Hajar Mataram ditolak.

Temuan ini menunjukkan arah pengaruh yang positif tetapi tidak signifikan artinya bahwa walaupun Direktur Rumah Sakit Islam Siti Hajar memimpin dengan sikap dan perilaku yang baik (dari sudut pandang Islam) tetapi kinerja Islami kurang meningkat atau dengan kata lain cara kerja, sikap dan perilaku pegawai dalam berkerja tidak mengalami banyak perubahan kearah yang lebih baik.

Kepemimpinan Islami tidak berpengaruh signifikan terhadap kinerja Islami. Hal ini dapat terjadi salah satunya dikarenakan masa jabatan pemimpin yang relatif singkat atau terjadinya pergantian pemimpin sebelum masa jabatannya berakhir yang berakibat negatif pada pegawai seperti terjadinya kebingungan pada pegawai dalam melaksanakan kebijakan yang berganti-ganti, turunnya motivasi kerja pegawai karena harus mengikuti aturan baru dan berkurangnya kepercayaan pegawai pada pemimpin.

Hasil penelitian ini berbeda dengan hasil-hasil penelitian terdahulu yang telah menemukan bahwa kepemimpinan Islami berpengaruh positif dan signifikan terhadap kinerja Islami seperti penelitian Shahab (2010), Hakim (2012) dan Wijayanti dan Wajdi (2012), Syamsuddin (2014) dan Lousyana (2015). Namun temuan penelitian ini mendukung beberapa penelitian terdahulu yang telah menemukan bahwa kepemimpinan Islami tidak berpengaruh signifikan terhadap kinerja Islami. Diantaranya adalah hasil penelitian Suparman (2012), Tongo (2014), Haryanti (2015) dan Mappamiring (2015).

\subsubsection{Pengaruh Etos Kerja Islami terhadap Kinerja Islami Pegawai}

Penelitian ini menemukan bahwa etos kerja Islami berpengaruh positif dan signifikan terhadap kinerja Islami pegawai pada Rumah Sakit Islam Siti Hajar Mataram. Hal ini menunjukkan bahwa apabila etos kerja Islami mengalami peningkatan maka kinerja Islami juga akan mengalami peningkatan. Berdasarkan hasil yang diperoleh pada penelitian ini, maka hipotesis yang menyatakan bahwa diduga etos kerja Islami berpengaruh positif dan signifikan terhadap kinerja Islami pegawai pada Rumah Sakit Islam Siti Hajar Mataram diterima.

Etos kerja Islami secara signifikan mampu memengaruhi kinerja Islami pegawai 


\section{$J M M$

Rumah Sakit Islam Siti Hajar Mataram. Hal ini terjadi karena pegawai telah memiliki etos kerja Islami yang tinggi hal ini salah satunya ditandai dari komitmen tinggi yang dimiliki pegawai. Sebagaimana hasil yang diperoleh pada penelitian ini bahwa responden yang berpartisipasi pada penelitian ini didominasi oleh pegawai yang memiliki masa kerja antara 6 samapai dengan 10 tahun. Masa kerja 6 sampai dengan 10 tahun dapat dikatakan usia kerja pegawai sudah lama atau senior. Jika merujuk pada karakteristik responden, pegawai Rumah Sakit Islam Siti Hajar Mataram lebih didominasi oleh pegawai yang memiliki masa kerja lebih dari 6 tahun. Hal ini mengindikasikan bahwa rata-rata pegawai Rumah Sakit Islam Siti Hajar Mataram sudah senior dan berpengalaman. Robbins (2006, p.84) menyatakan semakin tinggi masa kerja seorang karyawan mampunyai asumsi bahwa kemampuan kerjanya akan semakin baik, sehingga dengan masa kerja yang tinggi akan berpengaruh terhadap kinerja karyawan.

Masa kerja yang lama menandakan komitmen pada diri pegawai tinggi. Dengan komitmen yang tinggi pada organisasi akan mendorong pegawai untuk bersedia berkorban (tenaga, pikiran, waktu dan kesempatannya) untuk kepentingan dan tujuan organisasi. Sementara komitmen yang tinggi menandakan etos kerja Islami pada pegawai Rumah Sakit Islam Siti Hajar Mataram tinggi yang artinya apabila etos kerja Islami pegawai tinggi maka akan meningkatkan kinerja Islami pegawai.

Hasil penelitian ini sesuai dengan beberapa hasil penelitian terdahulu yang menemukan bahwa etos kerja berpengaruh positif dan signifikan terhadap kinerja seperti penelitian yang dilakuan Hayati dan Caniago (2012), Hayati dan Caniago (2012), Imam et al., (2013), Desky (2014), Nurmatias (2015) namun hasil penelitian ini berbeda dengan hasil penelitian Sutono dan Budiman (2009) yang menemukan etos kerja Islami tidak berpengaruh signifikan terhadap kinerja karyawan.

\subsubsection{Pengaruh Budaya Organisasi Islami terhadap Kinerja Islami Pegawai}

Penelitian ini menguji pengaruh budaya organisasi Islami terhadap kinerja Islami pegawai pada Rumah Sakit Islam Siti Hajar Mataram. Hasil penelitian membuktikan bahwa bahwa budaya organisasi Islami berpengaruh positif dan signifikan terhadap kinerja Islami pegawai. Hal ini menunjukkan bahwa apabila budaya organisasi di tingkatkan maka kinerja Islami pegawai juga akan mengalami peningkatan. Berdasarkan hasil yang diperoleh pada penelitian ini, maka hipotesis yang menyatakan bahwa diduga budaya organisasi Islami berpengaruh positif dan signifikan terhadap kinerja Islami Rumah Sakit Islam Siti Hajar Mataram diterima.

Hasil penelitian ini menemukan bahwa budaya organisasi Islami di Rumah Sakit Islam Siti Hajar Mataram termasuk kuat, hal ini menunjukkan bahwa unsur-unsur budaya organisasi Islami yang diterapkan di Rumah Sakit Islam Siti Hajar Mataram sudah dapat diimplementasikan secara baik oleh para pegawai. Sehingga hal ini diindikasi sebagai salah satu penyebab signifikannya pengaruh budaya organisasi Islami terhadap kinerja Islami. Diantara unsur-unsur budaya organisasi Islami pada penelitian ini adalah pegawai diharapkan bekerja atau memberikan pelayanan dengan penuh keikhlasan dan muraqabatullah. Dari hasil penilaian responden terhadap budaya organisasi Islami, unsur keikhlasan dan muraqabatullah mendapatkan penilaian tertinggi sehingga unsur ini dianggap kuat. Hal ini memberi arti bahwa para pegawai mendukung dan merasa bahwa ikhlas dan muraqabatullah memang sangat diperlukan dalam bekerja terlebih pekerjaan yang sifatnya melayani.

Dengan mengimplementasikan dan menanamkan keikhlasan dan muraqabatullah dalam bekerja akan memberikan dampak pada niat yang lurus, bekerja untuk ibadah mencari keridhaan Allah, menambah semangat kerja dan menambah kerelaan berkorban 


\section{$J M M$

untuk kepentingan dan tujuan organisasi sehingga kualitas kerja yang dihasilkan dapat memberikan kepuasan pada pelanggan. Dengan demikian budaya organisasi Islami yang kuat akan memberikan dampak pada peningkatan kinerja Islami pegawai atau dengan kata lain cara kerja, sikap dan perilaku pegawai dalam bekerja akan mengalami perubahan yang besar ke arah yang lebih baik sehingga hasil yang diperoleh lebih optimal.

Temuan penelitian ini mendukung hasil penelitian terdahulu yang menemukan bahwa budaya organisasi Islami berpengaruh positif dan signifikan terhadap kinerja Islami seperti penelitian Hakim (2012) dan Mappamiring (2015) yang juga memfokuskan penelitiannya pada budaya organisasi Islami dan kinerja Islami.

\subsubsection{Pengaruh Kepemimpinan Islami terhadap Kinerja Islami dengan dimoderasi} Budaya Organisasi Islami

Penelitian ini menguji pengaruh kepemimpinan Islami terhadap kinerja Islami dengan dimoderasi budaya organisasi Islami. Hasil penelitian menunjukkan bahwa budaya organisasi Islami tidak memperkuat pengaruh kepemimpinan Islami terhadap kinerja Islami. Berdasarkan hasil temuan yang diperoleh, maka hipotesis yang menyatakan bahwa diduga budaya organisasi Islami memperkuat pengaruh kepemimpinan Islami terhadap kinerja Islami pegawai Rumah Sakit Islam Siti Hajar Mataram ditolak.

Hasil penelitian ini dapat dikategorikan sebagai predictor moderasi (moderasi sebagai predictor) karena ketika budaya organisasi Islami sebagai prediktor atau sebagai variabel yang memengaruhi langsung kinerja Islami, hasil yang diperoleh adalah signifikan namun ketika berperan sebagai variabel yang memoderasi pengaruh kepemimpinan Islami terhadap kinerja Islami hasil yang diperoleh tidak signifikan.

\subsubsection{Pengaruh Kepemimpinan Islami terhadap Kinerja Islami dengan dimoderasi Budaya Organisasi Islami}

Penelitian ini menguji pengaruh etos kerja Islami terhadap kinerja Islami pegawai dengan dimoderasi budaya organisasi Islami. Hal ini menunjukkan bahwa dengan adanya etos kerja Islami didukung dengan budaya organisasi Islami terbukti mampu meningkatkan kinerja Islami pegawai. Berdasarkan hasil yang diperoleh pada penelitian ini, maka hipotesis yang mengatakan, bahwa diduga budaya organisasi Islami memperkuat pengaruh etos kerja Islami terhadap kinerja Islami pegawai Rumah Sakit Islam Siti Hajar Mataram diterima

Hasil penelitian ini menemukan bahwa budaya organisasi Islami memperkuat pengaruh etos kerja Islami terhadap kinerja Islami pegawai Rumah Sakit Islam Siti Hajar Mataram. Hal ini terjadi karena etos kerja Islami pegawai di Rumah Sakit Islam Siti Hajar Mataram tinggi dan budaya organisasi Islami yang diterapkan sudah termasuk dalam kategori kuat. Sehingga dengan tingginya etos kerja Islami pegawai dengan didukung budaya organisasi Islami yang kuat menjadikan kinerja Islami pegawai juga semakin baik atau meningkat.

Hasil penelitian ini dapat dikategorikan sebagai quasi moderasi (moderasi semu). Karena ketika budaya organisasi Islami sebagai prediktor atau sebagai variabel yang memengaruhi langsung kinerja Islami, hasil yang diperoleh adalah signifikan dan ketika budaya organisasi Islami berperan sebagai variabel yang memoderasi pengaruh etos kerja Islami terhadap kinerja Islami hasil yang diperoleh juga signifikan. 


\section{$J M M$

\subsection{Simpulan}

\section{Simpulan dan Saran}

Berdasarkan hasil analisis dan pembahasan hasil penelitian maka dapat diambil kesimpulan sebagai berikut:

1. Hubungan antara kepemimpinan Islami dengan kinerja Islami adalah positif atau searah. Sementara pengaruh dari kepemimpinan Islami terhadap kinerja Islami menunjukkan pengaruh yang tidak signifikan. Dengan demikian kepemimpinan Islami berpengaruh positif namun tidak signifikan terhadap kinerja Islami.

2. Hubungan antara etos kerja Islami dengan kinerja Islami adalah positif atau searah. Kemudian pengaruh etos kerja Islami terhadap kinerja Islami menunjukkan pengaruh yang signifikan. Dengan demikian etos kerja Islami berpengaruh positif dan siginifikan terhadap kinerja Islami pegawai.

3. Hubungan antara budaya organisasi Islami dengan kinerja Islami adalah positif atau searah. Kemudian pengaruh budaya organisasi Islami terhadap kinerja Islami menunjukkan pengaruh yang signifikan. Dengan demikian budaya organisasi Islami berpengaruh positif dan siginifikan terhadap kinerja Islami pegawai.

4. Hubungan antara variabel moderating effect 1 dengan kinerja Islami adalah negatif. Kemudian pengaruh variabel moderating effect 1 terhadap kinerja Islami tidak signifikan. Dengan demikian budaya organisasi Islami tidak memperkuat pengaruh kepemimpinan Islami terhadap kinerja Islami.

5. Hubungan antara variabel moderating effect 2 dengan kinerja Islami adalah positif. Kemudian pengaruh variabel moderating effect 2 terhadap kinerja Islami adalah signifikan. Dengan demikian budaya organisasi Islami memperkuat pengaruh etos kerja Islami terhadap kinerja Islami.

\subsection{Saran}

Sebagaimana telah dijelaskan secara deskriptif pada penelitian ini, kepemimpinan Islami termasuk variabel yang mendapatkan penilaian paling rendah jika dibandingkan dengan 3 variabel lainnya. Kepemimpinan Islami di Rumah Sakit Islami dinilai cukup baik. Hal ini mengindikasikan bahwa kepemimpinan Islami di Rumah Sakit Islam Siti Hajar Mataram masih perlu ditingkatkan sehingga nantinya dapat memberikan dampak atau pengaruh yang besar terhadap peningkatan kinerja Islami pegawai. Diantara hal-hal yang perlu ditingkatkan adalah pemberian penghargaan, pemberian motivasi dan meningkatkan pengawasan. Karena ketiga hal tersebut mendapatkan penilaian paling rendah dari responden. Rendahnya penilaian terhadap komitmen pada etos kerja Islami dan keikhlasan pegawai dalam bekerja pada kinerja Islami diindikasi karena penghargaan, motivasi dan pengawasan yang didapatkan masih belum optimal sehingga perlu ditingkatkan. Dengan demikian pemberian penghargaan, motivasi dan pengawasan hendaknya menjadi perhatian dan bahan evaluasi dalam upaya meningkatkan kinerja Islami pegawai.

Dalam penelitian ini masih terdapat perbedaan hasil penelitian dengan hasil penelitian sebelumnya sehinga perlu dilakukan penelitian secara lebih mendalam. Penelitian ini hanya terbatas pada pegawai Rumah Sakit Islam Siti Hajar Mataram oleh sebab itu bagi penelitian selanjutnya diharapkan untuk memperluas area sampel penelitiannya dan melakukan penelitian di lokasi yang berbeda. Bagi peneliti selanjutnya yang ingin meneliti dengan topik yang sama hendaknya menambah variabel lain yang dapat memengaruhi kinerja Islami, seperti kepuasan kerja Islami, iklim organisasi Islami, motivasi kerja Islami atau menambah variabel moderasi dengan variabel lainnya. 


\section{Daftar Pustaka}

Desky, H. (2014), "Pengaruh Etos Kerja Islami dan Gaya Kepemimpinan Terhadap Kinerja Karyawan Rumah Makan Ayam Lepaas Lhokseumawe", INFERENSI Jurnal Penelitian Sosial Keagamaan, VIII (2), 459-478.

Ghozali, I. \& Latan, H. (2015), Partial Least Squares Konsep, Teknik dan Aplikasi Menggunakan Program SmartPLS 3.0 Untuk Penelitian Empiris Edisi 2, Semarang: Universitas Diponegoro Semarang.

Gibson, Invancevich \& Donnelly (1996), Organisasi, Perilaku Struktur Proses, Jakarta: Binarupa Aksara.

Giri, E.E., Nimran, U., Hamid, D. \& Musadieq, M.A. (2016), "The Effect of Organizational Culture and Organizational Commitment to Job Involvement, Knowledge Sharing, and Employee Performance: A Study on Regional Telecommunications Employees of PT Telkom East Nusa Tenggara Province, Indonesia", International Journal of Management and Administrative Sciences (IJMAS), III (4), 20-33.

Hakim, A. (2012), "The Implementation of Islamic Leadership and Islamic Organizatioanal Culture and Its Influence on Islamic Working Motivation and Islamic Employee in the Central Java", Asia Pacific Management Review, XVII (1), 7790.

Haryanti, S. (2015), "Pengaruh Gaya Kepemimpinan, Budaya Organisasi, dan Kompetensi Karyawan Terhadap Kinerja dengan Komitmen Organisasional Sebagai Variabel Mediasi", Jurnal Bisnis \& Manajemen, XV (1), 33 - 44.

Hayati, K. \& Caniago, I. (2012), "Islamic Work Ethic: The Role of Intrinsic Motivation, Job Satisfaction, Organizational Commitment and Job Performance", Procedia - Social and Behavioral Sciences, LXV, 1102 - 1106.

Hussein, A.S. (2015), Modul Ajar Penelitian Bisnis dan Manajemen Menggunakan Partial Least Squares (PLS) dengan smartPLS 3.0, Malang: Universitas Brawijaya.

Imam, A., Abbasi, A.S. \& Muneer, S. (2013), "The Impact of Islamic Work Ethics on Employee Performance: Testing Two Models of Personality X and Personality Y", Sci.Int (Lahore), XXIII (3), 611-617.

Lina, D. (2014), "Analisis Pengaruh Kepemimpinan dan Budaya Organisasi Terhadap Kinerja Pegawai dengan Sistem Reward Sebagai Variabel Moderating", Jurnal Riset Akuntansi dan Bisnis, XIV (1), 77-97.

Lousyiana, T.T. \& Harlen (2015), "Pengaruh Gaya Kepemimpinan dan Budaya Organisasi Terhadap Kepuasan Kerja dan Kinerja Perawat di Rumah Sakit Islam Ibnu Sina Pekanbaru", Jurnal Tepak Manajemen Bisnis, VII (3), 509-521.

Mappamiring, P. (2015), "Effect of Cultural Organization, Leadership and Motivation of Work on the Performance of Employees (Studies in Islamic Banking in Makassar)", International Journal of Academic Research in Business and Social Sciences, V (12), 140166.

Nurmatias, F. (2015), "Pengaruh Etika Kerja Islam, Komitmen Organisasi Terhadap Kinerja Karyawan di Institut Agama Islam Tafaqquh Fiddin Dumai", Jurnal Tamaddun Ummah, I (1), 1-14.

Rivai, V., Bachtiar \& Amar, B.R. (2013), Pemimpin dan Kepemimpinan Dalam Organisasi, Jakarta: PT RajaGafindo Persada.

Rivai, V., Syam, F., Mujahidin, A., Asyari, S. \& Rizqullah (2010), Islamic Performance Appraisal For Human Capital Sistem Penilaian Kinerja SDM Secara Islami untuk Mengoptimalkan Kinerja Perusahaan, Jakarta: Gramata Publishing. 


\section{$J M M$

Setyorini, C.T. (2012), "Pengaruh Komitmen Organisasi, Budaya Organisasi, dan Keterlibatan Kerja Terhadap Kinerja Karyawan Baitul Mall Wat Tamwil (BMT)", II, (1), 32-47.

Shahab, M.A. (2010), "Implementasi Kepemimpinan dan Komitmen Serta Pengaruhnya Terhadap Kepuasan Kerja dan Kinerja Karyawan Persepektif Islam', JRBI, VI (2), 184-200.

Sugiyono (2002), Metode Penelitian Administrasi, Bandung: Alfabeta.

Sugiyono (2014), Metode Penelitian Kuantitatif Kualitatif dan RED, Bandung: Alfabeta.

Suparman, L. (2012), "Pengaruh Kompetensi Tuan Guru Terhadap Kepemimpinan Tuan

Guru, Prestasi Kerja dan Kesejahteraan Bawahan (Studi Pada Pondok Pesantren di Pulau Lombok)", Disertasi Program Pascasarjana Universitas Airlangga.

Suryo, B.D. (2010), "Pengaruh Gaya Kepemimpinan Transformasional, Budaya Organisasi dan Inovasi Terhadap Kinerja (Studi pada Panti Asuhan di Kota Tomohon dan Kabupaten Minahasa)", Jurnal Aplikasi Manajemen, VIII (2), 391-404.

Sutono \& Budiman, F.A. (2009), "Pengaruh Kepemimpinan dan Etos Kerja Islami Terhadap Kinerja Karyawan Di Koperasi Jasa Keuangan Syari'ah Baitul Maal Wat Tamwil di Kecamatan Rembang", Analisis Manajemen, IV (1), 11-28.

Sutrisno, E. (2015), Manajemen Sumber Daya Manusia, Jakarta: Kencana Prenada Media Group.

Syamsuddin (2014), "Penerapan Kepemimpinan Islam dan Pengaruhnya terhadap Kinerja Pengelola KSP Syariah di Kabupaten Wajo dan Kabupaten Enrekang", Jurnal Aplikasi Manajemen, XII (4), 716-722.

Tasmara, T. (2002), Membudayakan Etos Kerja Islami, Jakarta: Gema Insani.

Tongo-Tongo, Y., (2014), "Pengaruh Gaya Kepemimpinan Dan Disiplin Kerja Terhadap Kinerja Anggota Detasemen A Pelopo Satuan Brigade Mobil Kepolisian" Jurnal Riset Bisnis dan Manajemen, II (4), 103-07.

Wijayanti \& Wajdi (2012), "Pengaruh Kepemimpinan Islami, Motivasi dan Kepuasan Kerja Terhadap Kinerja Karyawan Dengan Lama Kerja Sebagai Variabel Moderating", DAYA SAING Jurnal Ekonomi Manajemen Sumber Daya, XIII (2), 108115.

Wirawan (2007), Budaya dan Iklim Organisasi, Teori Aplikasi dan Penelitian, Jakarta: Salemba Empat. 